\title{
Heat balance analysis in electric arc furnace for process improvement
}

\author{
Sandeep Ohol ${ }^{1, *}$, Mathew $V^{1}$, Savita Shinde ${ }^{l}$ and G. Balachandran ${ }^{2}$ \\ ${ }^{1}$ MIT School of Engineering, MIT ADT University, Pune (India) \\ ${ }^{2}$ JSW Bellary, (India)
}

\begin{abstract}
The current study deals with optimizing the melting process used in electric arc furnace by heat balance equations. Heat balance is a very important aspect in an arc furnace in which the energy input consists of electrical energy [65\%], chemical energy [25\%] and exothermic reaction heat $[10 \%]$. This energy is optimized with the charge mix, charge quantity, fluxes, fuel used, and $\mathrm{O} 2$ used in the burners. The present model considers all these aspects and gives heat distribution in the process. The model spreadsheet gives a reasonable prediction in terms of metal yield, composition, and energy consumption. The model also predicts the amount of iron oxidized in the process. The mass and heat balance model is a useful tool for process analysis and improves the process efficiency of electric arc furnace steelmaking.
\end{abstract}

Keywords Energy consumption analysis, Electric Arc Furnace, Steel scrap, Heat balance, Optimization

\section{Introduction}

The use of electric arc furnaces (EAF) for steelmaking has grown dramatically in the last few decades. Presently, around $36 \%$ of the steel produced is made by the electric arc furnace route and this is expected to further increase to $50 \%$ in the next few years. Electric Arc Furnace (EAF) is the most common way to recycle steel from scrap. By melting the scrap in a furnace with the help of electrodes and an electric current, new, functional steel can be produced from old products. Once the scrap has been melted and refined to the desired composition and temperature, the molten steel is tapped into a ladle for secondary treatment and casting. The international iron and steel institute classifies EAFs based on power supply per ton of furnace capacity. Power classification ranges are shown in the following Table 1[1]

Vladimir Viktorovich Pavlov and Oxana Sergeevna Logunova conducted the study of charging material at large integrated steel factory. They found that by using alternative material charge, consumption of specific energy is changed[1] Jens Wendelstorf and Karl-Heinz Spitzer developed a process reactor model which will be helpful to predict tapping temperature and meltdown ststus[2]. Dr. Bernd Kleimt and et al. conducted the energy balance of electric arc furnace and developed one dynamic model which will be helpful for online observation and dynamic process control[3]. Dragoljub Gajic and et al. developed one model which predicts the value of electrical energy consumption as a function of the chemical composition the charging mix[5]. Jens Wendelstorf developed online model which demonstrate meltdown of solid material and temperature development in the furnace[6]. Marcus Kirschen et al. conducted mass and energy balance of EAF melting process which gives information about chemical energy input and total energy demand of particular EAF process[7]. Bake lee and Il Sohn reviewed the energy innovations for EAF steel making route and found that preheating of scrap will lower the energy consumption by $90 \mathrm{kWh} / \mathrm{t}$. Bucket type and twin shell preheaters will also be effective in lowering overall power consumption by $60 \mathrm{kWh} / \mathrm{t}[8]$. Biau lo et al. analysed flow characteristics of ferriteflows and established an energy intensity production optimization model for production system in iron and steel industry. They suggested Unified resource deployment is the basic guarantee of the implementation of the optimization scheme. Therefore, resource sharing should be fully considered during the iron and steel company process design stage. The advanced energy saving technologies and measures, which favors production route re-optimizes, should be adopted in actual production process[9].

Using ultra-high power furnaces it is possible to increase productivity, reduce tap to tap time, and reduce electric energy consumption [1]

\footnotetext{
*Corresponding author: sandeepashu31@gmail.com
} 
Table 1 Electric power classification in the electric arc furnace

\begin{tabular}{|l|l|}
\hline \multicolumn{1}{|c|}{$\begin{array}{c}\text { Range of power } \\
\text { (KVA/t) }\end{array}$} & \multicolumn{1}{c|}{ Furnace type } \\
\hline $100-200$ & Low power \\
\hline $200-400$ & Medium power \\
\hline $400-700$ & High power \\
\hline $700-1000$ & Ultra-high power \\
\hline
\end{tabular}

\section{Experimental work}

\subsection{Experimental set up}

For this study, the electric arc furnace at Kalyani Carpenter Special Steels Limited, (KCSSL) Pune is used. The EAF at KCSSL has a capacity of $35 \mathrm{MT}$ and it is equipped with a 22 MVA transformer. The details of the furnace used for the study is shown in following Electric Arc Furnace at KCSSL.

-Make: ABB

-Melting capacity: 35 MT

-Transformer Power: 22 MVA

-Tapping: Slide gate assembly

-Two virtual lance burners

-Bucket Charging: Minimum Two charges per heat

- Continuous DRI feeding Conveyor

-Charge Mix: In house scrap; forging flashes, HMS, Pig iron, DRI

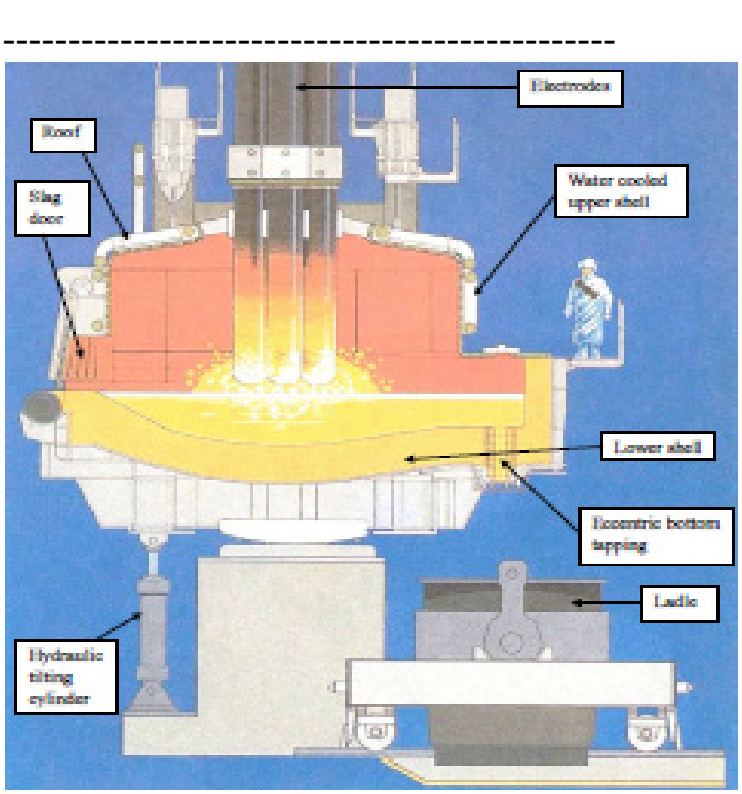

Fig. 1 Typical Electric Arc Furnace

There were one batch of experimentation that was carried out in the furnace

\subsection{Melting Technique}

Initially, the EAF roof is opened and about half of the total charge is charged into the furnace. After the initial charge, the roof is replaced on the furnace top and the furnace is powered on with a graphite electrode to generate electric arc. During the melting period, Virtual Lance Burners (VLB) run as per the computer preset program. The current and voltage selection is initially set and a profile for the melting set as per designed experimental requirements. After the initial lot is melted, the roof is opened and the second charge of another $30 \%$ of charge is added. After the second charge, the furnace is powered on and the VLB switched on. When all the $80 \%$ of charge is melted, a temperature reading is taken. When the temperature was greater than $1570^{\circ} \mathrm{C}$ The first metal sample for chemical analysis is taken. This is followed by the final 20\% charge addition consisting mainly of DRI, using a conveyor belt feeder. At the various stages of the above operation, metal and slag samples were taken for chemical analysis. The process events were continuously recorded from start to end. On attainment of desired chemical composition, the heat is tapped into a ladle for secondary refining. The typical processing cycle carried out in the experimental batch is shown in Table 2 The heat input, in terms of electric arc, was gradual. The various processing times at various stages such as charging, melting, refining, sampling, foaming, and tapping are given.

Table No. 2 EAF process details for the experimental batches

\begin{tabular}{|c|c|c|c|c|c|}
\hline \multicolumn{2}{|c|}{ Batch 1} & \multicolumn{2}{|r|}{ Batch 2} & \multicolumn{2}{|r|}{ Batch 3} \\
\hline $\begin{array}{l}\mathrm{Ti} \\
\mathrm{me} \\
(\mathrm{Mi} \\
\mathrm{n} .) \\
\end{array}$ & $\begin{array}{l}\text { Process } \\
\text { Details }\end{array}$ & $\begin{array}{l}\mathrm{Ti} \\
\mathrm{me} \\
(\mathrm{Mi} \\
\mathrm{n} .) \\
\end{array}$ & $\begin{array}{l}\text { Process } \\
\text { Details }\end{array}$ & $\begin{array}{l}\mathrm{Ti} \\
\mathrm{me} \\
(\mathrm{Mi} \\
\mathrm{n} .)\end{array}$ & $\begin{array}{l}\text { Process } \\
\text { Details }\end{array}$ \\
\hline $\begin{array}{ll}0 & - \\
3 & \end{array}$ & $\begin{array}{l}\text { The first } \\
\text { charge } \\
\text { added }\end{array}$ & $0-3$ & $\begin{array}{l}\text { First } \\
\text { charge } \\
\text { added }\end{array}$ & $0-3$ & $\begin{array}{l}\text { First charge } \\
\text { added }\end{array}$ \\
\hline $\begin{array}{l}3- \\
23\end{array}$ & $\begin{array}{l}\text { First } \\
\text { charge } \\
\text { melting }\end{array}$ & $\begin{array}{l}3- \\
52\end{array}$ & $\begin{array}{l}\text { Furnace } \\
\text { melting }\end{array}$ & $\begin{array}{l}3- \\
23\end{array}$ & $\begin{array}{l}\text { First charge } \\
\text { melting }\end{array}$ \\
\hline $\begin{array}{l}23 \\
- \\
26\end{array}$ & $\begin{array}{l}\text { The } \\
\text { second } \\
\text { charge } \\
\text { added }\end{array}$ & $\begin{array}{l}52- \\
55\end{array}$ & $\begin{array}{l}\text { Second } \\
\text { charge } \\
\text { added }\end{array}$ & $\begin{array}{l}23- \\
26\end{array}$ & $\begin{array}{l}\text { Second } \\
\text { charge adeed }\end{array}$ \\
\hline $\begin{array}{l}26 \\
- \\
44 \\
\end{array}$ & $\begin{array}{l}\text { Second } \\
\text { charge } \\
\text { melting }\end{array}$ & $\begin{array}{l}55- \\
74\end{array}$ & $\begin{array}{l}\text { Second } \\
\text { charge } \\
\text { melting }\end{array}$ & $\begin{array}{l}26- \\
44\end{array}$ & $\begin{array}{l}\text { Second } \\
\text { charge } \\
\text { melting }\end{array}$ \\
\hline $\begin{array}{l}44 \\
- \\
45\end{array}$ & $\begin{array}{l}\text { First slag } \\
\text { sample is } \\
\text { taken }\end{array}$ & $\begin{array}{l}74- \\
75\end{array}$ & $\begin{array}{l}\text { DRI } \\
\text { feeding } \\
\text { started }\end{array}$ & $\begin{array}{l}44- \\
45\end{array}$ & $\begin{array}{l}\text { First slag } \\
\text { sample taken }\end{array}$ \\
\hline $\begin{array}{l}45 \\
- \\
46 \\
\end{array}$ & $\begin{array}{l}\text { DRI } \\
\text { feeding } \\
\text { started }\end{array}$ & $\begin{array}{l}75- \\
77\end{array}$ & $\begin{array}{l}\text { First slag } \\
\text { sample } \\
\text { taken }\end{array}$ & $\begin{array}{l}45- \\
46\end{array}$ & $\begin{array}{l}\text { DRI feeding } \\
\text { start }\end{array}$ \\
\hline $\begin{array}{l}46 \\
- \\
50\end{array}$ & $\begin{array}{l}\text { Temperat } \\
\text { ure and } \\
\text { the first } \\
\text { metal } \\
\text { sample is } \\
\text { taken for } \\
\text { analysis }\end{array}$ & $\begin{array}{l}77- \\
79\end{array}$ & $\begin{array}{l}\text { Temperat } \\
\text { ure and } \\
\text { first } \\
\text { metal } \\
\text { sample } \\
\text { taken for } \\
\text { analysis }\end{array}$ & $\begin{array}{l}46- \\
50\end{array}$ & $\begin{array}{l}\text { Temperatur } \\
\text { e and first } \\
\text { metal } \\
\text { sample } \\
\text { taken for } \\
\text { analysis }\end{array}$ \\
\hline
\end{tabular}




\begin{tabular}{|c|c|c|c|c|c|}
\hline $\begin{array}{l}50 \\
- \\
55\end{array}$ & $\begin{array}{l}\text { Second } \\
\text { slag } \\
\text { sample is } \\
\text { taken/Fo } \\
\text { aming } \\
\text { and } \\
\text { temperat } \\
\text { ure } \\
\text { raising }\end{array}$ & $\begin{array}{l}79- \\
81\end{array}$ & $\begin{array}{l}\text { Second } \\
\text { slag } \\
\text { sample } \\
\text { taken }\end{array}$ & $\begin{array}{l}50- \\
54\end{array}$ & $\begin{array}{l}\text { Second } \\
\text { slag } \\
\text { sample } \\
\text { taken. } \\
\text { Foaming } \\
\text { and temp. } \\
\text { raising }\end{array}$ \\
\hline $\begin{array}{l}55 \\
- \\
56\end{array}$ & $\begin{array}{l}\text { Third } \\
\text { slag } \\
\text { sample is } \\
\text { taken }\end{array}$ & $\begin{array}{l}81- \\
86\end{array}$ & $\begin{array}{l}\text { Second } \\
\text { and third } \\
\text { slag } \\
\text { sample } \\
\text { taken }\end{array}$ & $\begin{array}{l}54- \\
55\end{array}$ & $\begin{array}{l}\text { Third slag } \\
\text { sample taken }\end{array}$ \\
\hline $\begin{array}{l}56 \\
- \\
58\end{array}$ & $\begin{array}{l}\text { Final } \\
\text { coke } \\
\text { injection }\end{array}$ & $\begin{array}{l}86- \\
89\end{array}$ & $\begin{array}{l}\text { Foa } \\
\text { ming } \\
\text { and } \\
\text { temp. } \\
\text { Raisi } \\
\text { ng }\end{array}$ & $\begin{array}{l}55- \\
58\end{array}$ & $\begin{array}{l}\text { Final coke } \\
\text { injection }\end{array}$ \\
\hline $\begin{array}{l}58 \\
- \\
59\end{array}$ & $\begin{array}{l}\text { DRI } \\
\text { feeding } \\
\text { ends }\end{array}$ & $\begin{array}{l}89- \\
91\end{array}$ & $\begin{array}{l}\text { Forth } \\
\text { slag } \\
\text { sample } \\
\text { taken } \\
\end{array}$ & $\begin{array}{l}58- \\
59\end{array}$ & $\begin{array}{l}\text { DRI feeding } \\
\text { ends }\end{array}$ \\
\hline $\begin{array}{l}59 \\
- \\
62\end{array}$ & $\begin{array}{l}\text { Tapping } \\
\text { temperat } \\
\text { ure } \\
\text { recorded }\end{array}$ & $\begin{array}{l}91- \\
94\end{array}$ & $\begin{array}{l}\text { Final } \\
\text { coke } \\
\text { injection, } \\
\text { DRI } \\
\text { feeding } \\
\text { ends } \\
\end{array}$ & $\begin{array}{l}59- \\
60\end{array}$ & Tapping \\
\hline $\begin{array}{l}62 \\
- \\
65\end{array}$ & $\begin{array}{l}\text { Fourth } \\
\text { slag } \\
\text { sample is } \\
\text { taken/ } \\
\text { Tapping } \\
\text { starts }\end{array}$ & $\begin{array}{l}94- \\
96\end{array}$ & Tapping & $\begin{array}{l}61- \\
62\end{array}$ & $\begin{array}{l}\text { Fourth slag } \\
\text { sample } \\
\text { taken, } \\
\text { Tapping } \\
\text { start }\end{array}$ \\
\hline
\end{tabular}

The process schedule for Batch-1 and Batch-3 were almost same. In Batch 2 a prolonged processing was carried out, where the melting was carried out in a progressive manner. The arcing was very gradual for initial charge melting till $80 \%$ of the charge. Parameters such as power consumed during the process due to electric energy input, fuel combustion through lance burners and carbon injection is shown in Table 3

Table No. 3 EAF input data for three batches

\begin{tabular}{|l|c|c|c|}
\hline Parameter & Batch 1 & Batch 2 & Batch 3 \\
\hline $\begin{array}{l}\text { Charge mix, } \\
\text { (MT) }\end{array}$ & 39.50 & 36.00 & 37.50 \\
\hline $\begin{array}{l}\text { Electric } \\
\text { energy } \\
\text { consumption, } \\
\text { (kWh/MT) }\end{array}$ & 384 & 424 & 428 \\
\hline $\begin{array}{l}\text { VLB oxygen } \\
\text { consumption } \\
(\mathrm{NM} / \mathrm{MT})\end{array}$ & 33.19 & 45.04 & 44.08 \\
\hline $\begin{array}{l}\text { VLB Fuel } \\
\text { consumption, } \\
\text { (Lit/MT) }\end{array}$ & 0.0045 & 0.0057 & 0.0052 \\
\hline $\begin{array}{l}\text { Carbon } \\
\text { injection, } \\
\text { (kg/MT) }\end{array}$ & 0.017 & 0.009 & 0.011 \\
\hline
\end{tabular}

The metallic and slag output from the furnace is shown in Table 4

Table No. 4 EAF output data for three batches

\begin{tabular}{|l|c|c|c|}
\hline Parameter & Batch 1 & Batch 2 & $\begin{array}{l}\text { Batch } \\
3\end{array}$ \\
\hline $\begin{array}{l}\text { Theoretical } \\
\text { metallic } \\
\text { output, MT }\end{array}$ & 36.612 & 34.894 & 34.421 \\
\hline $\begin{array}{l}\text { Actual } \\
\text { metallic } \\
\text { output, MT }\end{array}$ & 37.420 & 32.900 & 33.820 \\
\hline $\begin{array}{l}\text { Metallic } \\
\text { loss, MT }\end{array}$ & -0.807 & 1.994 & 0.6 \\
\hline $\begin{array}{l}\text { Theoretical } \\
\text { slag } \\
\text { output, MT }\end{array}$ & 6.273 & 4.920 & 5.396 \\
\hline $\begin{array}{l}\text { Actual slag } \\
\text { output, MT }\end{array}$ & 6.320 & 5.500 & 5.670 \\
\hline $\begin{array}{l}\text { Slag loss, } \\
\text { MT }\end{array}$ & -0.046 & -0.579 & -0.273 \\
\hline Yield \% & 94.73 & 91.38 & 90.18 \\
\hline
\end{tabular}

The theoretical energy required to convert solid steel to molten condition is in the range of $350 \mathrm{kWh} / \mathrm{ton}$. The EAF steelmaking is only 55 to $65 \%$ efficient and as a result the total equivalent. energy input is usually in the range of 400 to $550 \mathrm{kWh} /$ ton in modern operations. The energy input consists of more than half the energy input for the EAF is from electrical energy. Chemical energy from fuel contributes about $40 \%$ and $10 \%$ can come from the exothermic reaction heat. The chemical energy can be from the calorific value of the fuel the rate of heating is controlled by the fuel and oxygen burning rate. The output energy distribution shows that $60 \%$ of heat energy is contained in the superheated steel, slag carries about $10 \%$; other heat losses are about $30 \%$. Minimizing this can save process energy.

Table No. 5 Distribution of heat (in \%) from input to output in a typical EAF

\begin{tabular}{|l|l|l|l|}
\hline \multicolumn{2}{|c|}{ Heat Input } & \multicolumn{2}{c|}{ Heat Output } \\
\hline Parameter & $\%$ & Parameter & $\%$ \\
\hline $\begin{array}{l}\text { Electric } \\
\text { energy }\end{array}$ & $56-60$ & Liquid Steel & $55-60$ \\
\hline $\begin{array}{l}\text { Chemical } \\
\text { energy }\end{array}$ & $30-40$ & Cooling water & $8-10$ \\
\hline Burners & $5-10$ & Miscellaneous & $1-3$ \\
\hline & & Slag & $8-10$ \\
\hline Total & $\mathbf{1 0 0}$ & Total & $\mathbf{1 0 0}$ \\
\hline
\end{tabular}

Factors such as raw material composition, power input rates, and operating practices can alter the above balance. In operations utilizing a large amount of charge carbon or high carbon feed materials, up to $60 \%$ of the energy contained in the off-gas may have high calorific due to large quantities of uncombusted carbon monoxide. The recovery of this energy in the EAF could increase energy input by 8 to $10 \%$. Thus, it is important 
to consider such factors when evaluating the energy balance for given furnace operation.

\section{Governing equations}

\subsection{Governing equations for mass balance}

1) Governing equation for this mass balance model is as

$\Sigma \mathrm{M}_{\text {input }}=\Sigma \mathrm{M}_{\text {output }}+\Sigma \mathrm{M}_{\mathrm{ls}}$

where $\Sigma \mathrm{M}_{\text {input }}=\mathrm{M}_{\mathrm{Scr}}+\mathrm{M}_{\mathrm{flx}}+\mathrm{M}_{\mathrm{ck}}+\mathrm{M}_{\mathrm{dm}}+\mathrm{M}_{\mathrm{bd}}+$ $\mathrm{MO}_{2}$ blown

$\Sigma M_{\text {output }}=M_{\text {st }}+M_{\text {sl }}+M_{\text {dust }}+M_{\text {gases }}$

2) Iron balance

$\mathrm{W}_{\mathrm{Fe}}{ }^{\mathrm{DRI}} \cdot \mathrm{M}_{\mathrm{DRI}}+\mathrm{W}_{\mathrm{Fe}}{ }^{\mathrm{Scr}} \cdot \mathrm{M}_{\mathrm{Scr}}+\mathrm{W}_{\mathrm{Fe}}{ }^{\mathrm{Flx}} \cdot \mathrm{M}_{\mathrm{Flx}}=\mathrm{W}_{\mathrm{Fe}}{ }^{\mathrm{St}} \cdot \mathrm{M}_{\mathrm{St}}+$ $\mathrm{W}_{\mathrm{Fe}}{ }^{\mathrm{Sl}} \cdot \mathrm{M}_{\mathrm{Sl}}+\mathrm{W}_{\mathrm{Fe}}{ }^{\text {dust }} \cdot \mathrm{M}_{\text {dust }}$

3) Silicon balance

$$
\begin{aligned}
& \mathrm{W}_{\mathrm{Si}}^{\mathrm{DRI}} \cdot \mathrm{M}_{\mathrm{DRI}}+\mathrm{W}_{\mathrm{Si}}^{\mathrm{Scr}} \cdot \mathrm{M}_{\mathrm{Scr}}+\mathrm{W}_{\mathrm{Si}}^{\mathrm{Flx}} \cdot \mathrm{M}_{\mathrm{Flx}}=\mathrm{W}_{\mathrm{Si}}^{\mathrm{St}} \cdot \mathrm{M}_{\mathrm{St}}+ \\
& \mathrm{W}_{\mathrm{Si}}^{\mathrm{sl}} \cdot \mathrm{M}_{\mathrm{sl}} \ldots \ldots \ldots \ldots \ldots \ldots \ldots \ldots \ldots \ldots \ldots \ldots \ldots \ldots \ldots \ldots \ldots \\
&
\end{aligned}
$$

Total

$$
\begin{aligned}
& \mathrm{M}_{\mathrm{Scr}}+\mathrm{M}_{\mathrm{DRI}}+\mathrm{M}_{\mathrm{Flx}}+\mathrm{M}_{\mathrm{O} 2}^{\text {blown }}+\mathrm{M}_{\text {coke }}=\mathrm{M}_{\mathrm{st}}+\mathrm{M}_{\mathrm{sl}}+\mathrm{M}_{\mathrm{dust}} \\
& \mathrm{M}_{\text {gases }} \ldots \ldots \ldots \ldots \ldots \ldots \ldots \ldots \ldots \ldots \ldots \ldots \ldots \ldots \ldots \ldots \ldots \ldots \ldots
\end{aligned}
$$

Where

$\mathrm{W}_{\mathrm{i}}^{\mathrm{j}}=$ Weight percent of specie $\mathrm{i}$ in phase $\mathrm{j} \mathrm{M}_{\text {input }}=$ Mass of all input scrap material.

$\mathrm{M}_{\text {output }}=$ Mass of all output material

$\mathrm{M}_{\mathrm{ls}}=$ Mass of losses

$\mathrm{M}_{\mathrm{Scr}}=$ Mass of scrap

$\mathrm{M}_{\mathrm{Flx}}=$ Mass of fluxes

$\mathrm{M}_{\mathrm{ck}}=$ Mass of coke

$\mathrm{M}_{\mathrm{dm}}=$ Mass of deoxidizing material

$\mathrm{M}_{\mathrm{bd}}=$ Mass of fuel

$\mathrm{M}_{\mathrm{O} 2} \stackrel{\text { blown }}{=}$ Mass of $\mathrm{O}_{2}$ blown into the furnace
$\mathrm{M}_{\mathrm{st}}=$ Mass of steel

$\mathrm{M}_{\mathrm{sl}}=$ Mass of slag

$\mathrm{M}_{\text {dust }}=$ Mass of dust $\mathrm{M}_{\mathrm{DRI}}$

Mass balance analysis of steel production process has been carried out according to the input component, and using mass conservation law as mentioned in above equations.

\section{Results and discussion}

Heat balance is another important aspect of an electric arc furnace which enables optimization of process conditions to minimize the energy consumption. This enables energy management from the charge point of view. The broad energy parameters for three experimental batchs is shown in Table 6

Table No. 6 Heat balance for the experimental batches

\begin{tabular}{|c|c|c|c|c|}
\hline $\begin{array}{c}\text { Fuel } \\
\text { used Kg }\end{array}$ & $\begin{array}{c}\text { Fuel heat } \\
\text { in } \\
\mathbf{k W h} / \mathbf{M T}\end{array}$ & $\begin{array}{c}\text { Electric } \\
\text { heat in } \\
\mathbf{k W h} / \mathbf{M T}\end{array}$ & $\begin{array}{c}\text { Chemical } \\
\text { heat } \\
\mathbf{k W h} / \mathbf{M T}\end{array}$ & $\begin{array}{c}\text { Total } \\
\text { energy } \\
\text { consumed } \\
\mathbf{k W h} / \mathbf{M T}\end{array}$ \\
\hline 170 & 47.02 & 384.00 & 238.08 & 622.08 \\
\hline 187 & 58.83 & 424.00 & 227.24 & 649.42 \\
\hline 176 & 53.86 & 428.00 & 287.80 & 706.88 \\
\hline
\end{tabular}

The Fig. 2 shows that fuel used is moderately higher for Batch-2. The electrical heat input increases from Batch-1 to Batch-3. The heat input due to stoichiometric exothermic heat generated by various steel making reactions is moderately higher for Batch-3 compared to the other two batches. The overall heat used in the process increases from Batch 1 to Batch 3 progressively. It is seen that average $63 \%$ of heat comes from electrical energy and average $37 \%$ of heat from fuel burnt in the furnace and the exothermic reaction heat varies from 7 to $9 \%$ due to exothermic reaction. This is important as minimising electrical energy saves energy cost, and this energy itself is produced with fuel combustion elsewhere. Hence, usage of fuel in furnace to generate heat is good. The present experiments shows 34 to $40 \%$ and possibility of enhancing this should be explored. However, this also increases emissions in the factory and the cost of this and impact on surrounding have to be assessed. The exothermic heat is $<9 \%$. To maximise this may be increasing carbon containing charge such as pig iron may be of helpful. The impact of this on the energy saving and productivity has to be assessed. Further pig iron is more expensive than scrap. The model developed can now be run to predict the theoretical power generation for a given charge mix. 


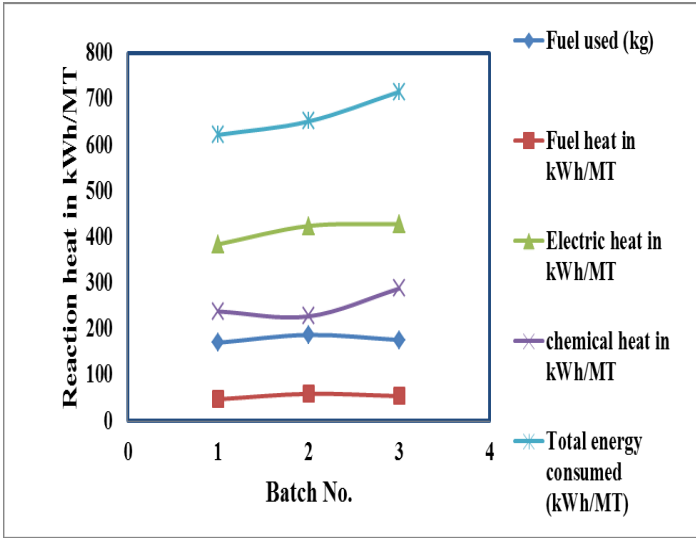

Fig. No. 2 Heat balance in the experimental batches

\section{Summary and Conclusion}

Three experimental trials were carried out in electric arc furnace at KCSSL to understand the process behaviour at various stage of processing. The elemental and slag constituents were tracked by studying the chemistry of the raw materials input and the output metal and slag obtained in the furnace. The model does the energy balance in the process and it is possible to optimise the electric energy consumption and fuel based energy and exothermic heat inputs. Using the model, it is now possible to reduce the process time, fuel, electric energy and oxygen consumption.

\section{Acknowledgement}

We thank the organisation KCSSL for providing the experimental facility.

\section{References}

1 Jeremy Jones, The EPRI centre for material production, C M R I, Pittsburgh, PP 1 (1997)

2 F. P. Edneral, vol. 1 Electric steelmaking, Mir publishers, Moscow, PP 17 (1979)

3 Richard J. Fruehan, AISI steel foundation, 11th edition, steelmaking and refining volume, chapter 10, (1998)

4 Yuri N. Toulouevski and Iiyaz Y. Zinurov, Scientific basis for selection, Springer, pp 1, (2010)

5 Ali Akbar Mottahedi et al, Int. J. of chemTech re, Vol.1,No1, pp 62 (2009)

6 F. Grobler and R.C.A. Minnitt, The Jr. of SouthAfrican inst. of mining and metallurgy, (1999)

7 R. J. fruehan, Y. Li, L. Brabie, Carnegie Mellon University, Pittsburgh.

8 Richard J. Fruehan, the AISI steel foundation, 11th edition, steelmaking and refining volume, chapter 2 (1998)
9 Jernkontoret, Sweden. [online]. Available: http://www.jernkontoret.se(2006, May 17).

10 Jacob paulraj, Steel world, pp 26 (2007)

11 Marcus Kirschen, Victor Risonarta, Herbert Pfeifer, Energy 34, pp 1065, (2009)

12 Ismail Ekmekci, YasarYetisken, UnalCamdali, Int. Jr. of iron and steel re., 14(05) pp 01, (2007)

13 Karl R. Haapala and John W. Sutherland(20), Annals of the CIRP vol. pp 1, (2007) 